Article

\title{
Research on Coordination and Driving Factors of Sports Industry and Regional Sustainable Development-Empirical Research Based on Panel Data of Provinces and Cities in Eastern China
}

\author{
Shaoxiong Yang ${ }^{1}$, Jinfu $\mathrm{Xu}^{2, *}$ and Ruoyu Yang ${ }^{3}$ \\ 1 School of Physical Education and Sport Science, Fujian Normal University, Fuzhou 350108, China; \\ yangshaoxiong@fjnu.edu.cn \\ 2 Sports Industry Development Research Center, Fujian Jiangxia University, Fuzhou 350108, China \\ 3 College of Management and Economics, Tianjin University, Tianjin 300072, China; yangruoyu@tju.edu.cn \\ * Correspondence: xujinfu@fjjxu.edu.cn
}

Received: 14 December 2019; Accepted: 20 January 2020; Published: 22 January 2020

check for updates

\begin{abstract}
The steady and healthy development of the sports industry can promote regional sustainable development. In order to explore the coordination situation and driving factors between the sports industry and regional sustainable development, this article builds a coupling coordination evaluation index system and dynamic factor index system for the sports industry and regional sustainable development. Using the entropy method, coupling coordination model and random effect model, this article analyzes the comprehensive level, coupling coordination relationship and driving factors of the sports industry and regional sustainable development in eleven provinces and cities in eastern China, from 2013 to 2017. The results show that the comprehensive level of the sports industry and regional sustainable development in eastern China is showing a steady growth trend, and the sports industry is growing faster than regional sustainable development. The degree of coupling coordination among provinces and cities has increased significantly, but the spillover effects of coupling coordination in each region are not obvious. The level of overall coupling coordination is primary coordination; regional innovation, industrial structure upgrade, and human capital can promote the improvement of coupling coordination. Therefore, it is necessary to strengthen cross-regional cooperation, build a cross-regional "sports+" industry group, give play to the "sports + " spillover effect, create a coupling platform for the sports industry and regional sustainable development, release the superimposed effect of multiple driving factors, and facilitate the evolution of coupling coordination to higher levels.
\end{abstract}

Keywords: sports industry; regional sustainable development; coupling coordination; driving factors; eastern China

\section{Introduction}

The rapid development of urban economy and industrial civilization has intensified the pressure on natural resources and the environment, resulting in sharp declines in resources, ecological damage, and environmental pollution in various countries, which seriously restricts human survival and long-term economic development [1]. The World Commission on Environment and Development introduced the concept of sustainable development for the first time in the book Our Common Future in 1987 and defined sustainable development as development that meets the needs of contemporary people without compromising the development of future generations [2]. The 1992 United Nations Conference on Environment and Development made the sustainable development initiative a common development strategy for all mankind. Since then, the need for sustainable development in countries 
around the world has become increasingly urgent. In 1997, China listed sustainable development as a national strategy at the Fifteenth National Congress. Since then, sustainable development has been a concept of social development. However, as Wilbankss pointed out, the basic concepts of sustainable development are relatively abstract. If we want to analyze sustainable development strategies as problems, we must take "sustainable development" as a specific research object, that is, apply it on a specific geographic area [3]. Therefore, sustainable development must be implemented into a specific "geographical area", which proposes regional sustainable development. The core of regional sustainable development is development. We must not only achieve the goal of economic development, but also promote the continuous improvement of social systems and population quality, and at the same time protect the natural resources and environment on which human beings depend [4]. Regional sustainable development regards the area as a dynamically changing system and studies the degree of coordination between the growing demand for development inside the area and the constraints on resources and the environment from the "social-economic-ecological" 3D goal, which is the basis for national sustainable development and global sustainable development [5].

In 2015, the United Nations released Transforming Our World-The 2030 Agenda for Sustainable Development, which took sports as a sustainable development method for the first time and clearly stated: "Sports is an important driving force for sustainable development. The contribution of sports to the realization of development and peace is increasing because sport promotes tolerance and respect, empowers women and youth, individuals and society, and contributes to health, education and social inclusion goals" [6]. As a green industry and a rising industry, the sports industry has the characteristics of expanding domestic demand, increasing employment, and cultivating new economic growth points. It can promote regional sustainable development. Regional sustainable development can also provide support and guarantee the prosperity of the sports industry [7]. The sports industry is of great significance to regional sustainable development [8]. The sports industry refers to the collection of the same kind of economic activities that provide sports products for the society and the integration of the same kind of economic sectors [9]. In October 2014, the State Council's "Several Opinions on Accelerating the Development of the Sports Industry and Promoting Sports Consumption" (referred to as "Circular 46") was released, which means that China will formally add the sports industry as a major industry into the national economic system. Relevant data show that the added value of China's sports industry in 2013 was 356.3 billion yuan, and the added value of China's sports industry in 2017 reached 781.1 billion yuan. In just a few years, the added value of the sports industry has increased to nearly 2.2 times its prior value. In recent years, China's economic development has entered a new normal, the economic growth rate has continued to decline, ecological and environmental problems have become increasingly serious, the power of manufacturing, investment, and export stimulus is insufficient, and the driving force for economic growth has been gradually replaced by innovation-driven and consumption-driven forces [10]. In contrast, the sports industry has shown sustained and rapid development and the added value of the sports industry has repeatedly hit record highs, making it a new force in China's economic growth and economic transformation and upgrading, and its strategic position in the national economic and social development has become more prominent. There must be a complementary relationship between the sports industry and regional sustainable development. Therefore, under the context of sports power and sustainable development rising to China's national strategy, exploring the current status of the sports industry and regional sustainable development and the coupling and coordination of the two can provide a scientific basis for the government to fully promote the development of the sports industry and also further enriched the theoretical connection between the sports industry and regional sustainable development.

\section{Literature Review}

Since the concept of sustainable development was put forward, scholars have carried out a series of related studies, mainly including: research on the sustainable development of urban development and the carrying capacity of resources and the environment [11], sustainable development 
research of economic growth and social equity [12,13], sustainable development research on human development and the environmental ecosystem [14], and regional sustainable development evaluation research [15-17]. With the continuous deepening of scholars' research on sustainable development, research that combines related industries with regional sustainable development and explores the coupling coordination between the two has also attracted scholars' attention. Zhao et al. analyzed the coupling coordination degree of China's tourism industry and regional sustainable development using the entropy method and coupling coordination model on the basis of exploring the interaction mechanism between the tourism industry and regional sustainable development [10]. The research results show that the degree of coupling coordination between the two has steadily increased, but it still takes time to achieve a high coordination. Zhao et al. used the entropy method, coupling coordination model and exploratory spatial data analysis method to analyze the coupling coordination degree and spatio-temporal differentiation characteristics of China's scientific and technological innovation industry and regional sustainable development [18]. The result shows that they are entering the stage of highly coupled coordination, but the degree of spatial agglomeration of the degree of coupling coordination is not significant. In addition, scholars also separately explored the interrelationships between related industries such as the Natural resources industry [19], agriculture [20], and manufacturing [21] and regional sustainable development.

The research results of the sports industry and regional sustainable development mostly focus on the research into the sports industry and regional economy. In the early stage, scholars used qualitative methods to describe the relationship between the sports industry and economic development [22], the status and role of the sports industry in the economic and social development of the new century, etc. $[23,24]$. With the continuous expansion of the sports industry system, the promotion effect of the sports industry on economic development has gradually emerged. The interaction between sports competition performances [25], national traditional sports culture [26], sports equipment manufacturing [27] and other related sports industries and regional economies have begun to attract scholars' attention. Scholars explored the relationship between the two by combining qualitative and quantitative methods. For example, Watson et al. explored the contribution of the golf industry to the regional economy in the Colorado region by constructing input-output models, and found that golf course operations and tourism alone produced an economic contribution of 160 million USD [28]. Baumann et al. used the number of flight arrivals to determine the change in the number of tourists in Hawaii during the hosting of sports events and found that sports events have a significant role in increasing the number of tourists, and that the hosting of events also has a role in promoting economic growth in Hawaii [29]. Schulenkorf et al. pointed out that sports events can bring benefits to the host's economic, socio-cultural and health aspects, and, through qualitative investigation, explored the management strategy to maintain the business vitality and community interests of sports activities [30]. A series of studies have shown that the development level of the regional economy is the basis of the development of the sports industry and determines the level and speed of the development of the sports industry. The development of the sports industry is an important means to promote the development of the regional economy and society [31,32]. However, as the world economy fluctuates and competition intensifies, and with the reflection on resource consumption brought by global climate change, the research scope of regional development has been extended from a single economic development to the fields of social security, ecological protection, etc. [33,34]. Therefore, the study of regional development should not be limited to the study of the regional economy. Factors such as social security and the ecological environment should also be analyzed. The social environment is the external environment for the development of the sports industry. With the development of the sport-for-development (SFD) field, more and more scholars have been discussing topics related to sports and the social environment [35]. Schulenkor has investigated the role of sports events in contributing to reconciliation and inclusive social change between disparate communities in ethnically divided Sri Lanka. He found that sports events can promote the friendship of different ethnic groups; at the same time, it is also a booster and catalyst for social change and development, and can make a significant contribution to 
social peace [36]. Later, Schulenkorf pointed out that carrying out sports activities can promote social cohesion and empower society, and proposed a Sport-for-Development (S4D) framework to encourage the promotion of social sustainable development through sports activities [37].

To sum up, the current research on the sports industry and regional sustainable development mostly focuses on the research between the sports industry and the regional economic or social environment. It lacks systematic research on regional sustainable development as a whole and deep thinking on the relationship between the sports industry and regional sustainable development in the new era. Lindsey and other scholars pointed out that sport is an "important promoter" of the 2030 Agenda for Sustainable Development and its sustainable development goals [38]. Therefore, it is necessary and meaningful to carry out relevant research on the relationship between the sports industry and regional sustainable development. The eleven provinces are the most developed regions in China's society and economy, and the development speed of the sports industry is also better than in other regions. Studying the industry layout of the sports industry in the eastern region has a demonstration effect on the development of other regions [39]. Therefore, this article uses the panel data of the sports industry and regional sustainable development indicators in eleven provinces and cities in eastern China from 2013 to 2017 as its basis, and uses the entropy method and coupling coordination model to analyze the comprehensive level and the degree of coupling coordination between the sports industry and regional sustainable development. Based on this, a dynamic factor analysis of the degree of coupling and coordination is conducted, in order to understand the comprehensive level of the sports industry and regional sustainable development in eastern China, the state of coupling and coordination between the two, and various factors affecting the degree of coupling and coordination. This also provides a useful reference for the further integration development of the sports industry and regional sustainable development.

\section{Research Methods}

\subsection{Entropy Method}

The entropy weighting approach is not affected by the linearity of the evaluation data. The weight is determined according to the variability of the index and the meaning of the index value, which effectively avoids the interference of human factors. The assignment process is transparent and reproducible, so the weights have high credibility [40,41]. Therefore, this article uses the entropy method to calculate the comprehensive level index of the sports industry and regional sustainable development. The specific steps are as follows:

Step 1: Because the dimensions and units of each indicator are different, they cannot be directly compared and calculated. Therefore, the indicator weights need to be standardized before being calculated [42]. When the selected indicator is a positive indicator, the normalization formula is $x_{i j}^{\prime}=\frac{x_{i j}-x_{j}^{\min }}{x_{j}^{\max }-x_{j}^{m i n}}$, when the selected indicator is a negative indicator, the normalization formula is $x_{i j}^{\prime}=\frac{x_{j}^{m i n}-x_{i j}}{x_{j}^{\max }-x_{j}^{\min }}$. In the formula, $x_{i j}$ represents the actual value of the $j$ index of the $i$ year, $x_{j}^{\max }$ and $x_{j}^{\min }$ represent the maximum and minimum values of the index $j, x_{i j}^{\prime}$ represents the standardized data of the $j$ index of the $i$ year;

Step 2: Considering that as, after the standardization of individual indicator values, when using the entropy method to obtain weights, calculating logarithms is meaningless because the minimum value of standardized data is zero, the normalized values need to be translated to further eliminate the above phenomenon. The translation processing formula is $X_{i j}=H+x_{i j}^{\prime}$, where $H$ is the magnitude of the index translation, and the value is 1 ;

Step 3: After the translation process, the data is dimensionless using the specific gravity method, and calculate the proportion of each index value in the evaluation system. The formula is $y_{i j}=\frac{X_{i j}}{\sum_{i=1}^{n} X_{i j}}$; 
Step 4: The formula for calculating the entropy value of the $j$ index is $e_{j}=-\frac{1}{l n n} \sum_{i=1}^{n} y_{i j} \ln y_{i j}$, the formula for calculating the difference coefficient is $g_{j}=1-e_{j}$, where $j=1,2, \cdots \cdots n, n$ is the number of indicators;

Step 5: The formula for calculating the weight of the $j$ index is $\omega_{j}=\frac{g_{j}}{\sum_{j=1}^{n} g_{j}}$;

Step 6: Calculate the comprehensive level index of the sports industry and regional sustainable development by using standardized data and the weights of various indicators. The formula is $Z_{i}=\sum_{j=1}^{p} \omega_{j} X_{i j}$.

\subsection{Coupling Coordination Model}

Based on the concept and principle of coupling in physics, this paper analyzes the coupling effect and coordination degree in the integration process of the sports industry and regional sustainable development. Because the sports industry and regional sustainable development have strong permeability and relevance, the interaction between the two can be studied using the theory of coupling coordination. The coupling coordination model consists of a coupling degree and a coupling coordination degree. The coupling degree is used to measure the strength of the interaction between systems. The coupling coordination degree reflects the relationship between coordination and a virtuous circle among the systems [43].

The calculation formula of the coupling degree is $C=\left[\frac{U \times G}{(U+G)^{2}}\right]^{\frac{1}{2}}, U$ and $G$ respectively represent the comprehensive level index of the sports industry and regional sustainable development. The calculation formula for the degree of coupling coordination is $D=\sqrt{C \times T}$. In the formula, $T$ is the overall comprehensive evaluation index of the sports industry and regional sustainable development, $\mathrm{T}=$ $\alpha \mathrm{U}+\beta \mathrm{G}, \alpha$ and $\beta$ are undetermined coefficients and, after consulting five relevant field experts, both $\alpha$ and $\beta$ are assigned a value of 0.5 . In order to intuitively reflect the coordination of the sports industry and regional sustainable development, refer to Liu et al. for a study on the classification of the degree of coupling coordination [44], and classification of the degree of coupling coordination of the two major system developments (Table 1).

Table 1. The degree of coupling coordination and level classification.

\begin{tabular}{ccc}
\hline Coupling Coordination Level & Level Classification & Coupling Coordination Degree (D) \\
\hline Extreme imbalance & & $(0,0.1)$ \\
Severe imbalance & Germination stage & $(0.1001,0.2)$ \\
Moderate imbalance & & $(0.2001,0.3)$ \\
Mild imbalance & & $(0.3001,0.4)$ \\
\hline Little imbalance & \multirow{2}{*}{ Start stage } & $(0.4001,0.5)$ \\
Barely coordination & & $(0.5001,0.6)$ \\
\hline Primary coordination & Steady stage & $(0.6001,0.7)$ \\
Intermediate coordination & & $(0.7001,0.8)$ \\
\hline Good coordination & \multirow{2}{*}{ Maturity stage } & $(0.8001,0.9)$ \\
Excellent coordination & & $(0.9001,1)$ \\
\hline
\end{tabular}

\section{Index System Construction}

The interaction between the sports industry and regional sustainable development is relatively complicated, and it is not a one-to-one linear relationship. Scholars believe that the research on coupling coordination of complex systems with coupled interactions should be based on the comprehensive evaluation of two systems and multiple indicators [45]. Based on the principles of scientific, reliability, orientation, pertinence, and data availability, this study establishes the sports industry indicator system by referring to the indicator system established by Yao et al., Yan, Ye, and others [32,46,47]. At the same time, it draws on the regional sustainable development indicator system, set by the 
"social-economic-ecological" three-dimensional research goal proposed by the academician of the Chinese Academy of Sciences Dadao Lu for regional sustainable development [5]. With reference to the index systems of Zhao et al. and Shi et al., it determined the three categories of economic, social, and ecological indicators $[33,48]$, consulting ten experts in the field of cooperative and coordinated evaluation index systems for sports industry-regional sustainable development to further optimize the index system. Based on the above principles and methods, starting from the six dimensions of industrial economic benefits, employment effects, industrial support conditions, economic development, social security, ecological environment, etc., we selected 23 individual indicators in detail and established a coordinated evaluation index system for sports industry-regional sustainable development (Table 2). Among them, the urban population density, the proportion of the illiterate population aged 15 and over, the urban registered unemployment rate, sulfur dioxide emissions, and nitrogen oxides indicators are negative, and the rest of the indicators are positive. All the data in this study are from the statistical yearbook published publicly by the National Bureau of Statistics of China. The data of China Statistical Yearbook is published by the National Bureau of Statistics, and the data of China Statistical Yearbook of the Tertiary Industry were jointly released by the National Bureau of Statistics and the Central Propaganda Department.

Table 2. Evaluation index system for the coupling coordination of the sports industry and regional sustainable development.

\begin{tabular}{|c|c|c|c|c|}
\hline System Layer & Dimension Layer & Indicator Layer & Weights & Data Source \\
\hline \multirow{8}{*}{ Sports industry } & \multirow{2}{*}{ Economic benefits } & $\begin{array}{c}\text { Operating income of legal } \\
\text { entities of sports enterprises } \\
\text { (100 million yuan) }\end{array}$ & 0.112 & $\begin{array}{c}\text { China Statistical } \\
\text { Yearbook of Tertiary } \\
\text { Industry }\end{array}$ \\
\hline & & $\begin{array}{l}\text { Sports lottery sales }(10,000 \\
\text { yuan })\end{array}$ & 0.134 & $\begin{array}{c}\text { The official website of } \\
\text { the Chinese Ministry } \\
\text { of Finance }\end{array}$ \\
\hline & \multirow{3}{*}{ Employment effect } & $\begin{array}{l}\text { Employment in Sports Town } \\
\text { Units }(10,000 \text { people })\end{array}$ & 0.117 & $\begin{array}{c}\text { China Statistical } \\
\text { Yearbook of Tertiary } \\
\text { Industry }\end{array}$ \\
\hline & & $\begin{array}{c}\text { Average wage of employed } \\
\text { persons in sports urban } \\
\text { units (yuan) }\end{array}$ & 0.108 & $\begin{array}{c}\text { China Statistical } \\
\text { Yearbook of Tertiary } \\
\text { Industry }\end{array}$ \\
\hline & & $\begin{array}{l}\text { Number of Sports Legal } \\
\text { Person Units (a) }\end{array}$ & 0.115 & $\begin{array}{c}\text { China Statistical } \\
\text { Yearbook of Tertiary } \\
\text { Industry }\end{array}$ \\
\hline & \multirow{3}{*}{ Support conditions } & Number of stadiums (a) & 0.193 & $\begin{array}{c}\text { China's Sixth } \\
\text { National Stadium } \\
\text { Census }\end{array}$ \\
\hline & & $\begin{array}{l}\text { Total social investment in } \\
\text { fixed assets of sports } \\
\text { enterprises ( } 100 \text { million } \\
\text { yuan) }\end{array}$ & 0.127 & $\begin{array}{l}\text { China Statistical } \\
\text { Yearbook of Tertiary } \\
\text { Industry }\end{array}$ \\
\hline & & $\begin{array}{c}\text { Local fiscal sports } \\
\text { expenditure (100 million } \\
\text { yuan) }\end{array}$ & 0.095 & $\begin{array}{l}\text { China Statistical } \\
\text { Yearbook of Tertiary } \\
\text { Industry }\end{array}$ \\
\hline
\end{tabular}


Table 2. Cont.

\begin{tabular}{|c|c|c|c|c|}
\hline System Layer & Dimension Layer & Indicator Layer & Weights & Data Source \\
\hline \multirow{15}{*}{$\begin{array}{c}\text { Regional } \\
\text { sustainable } \\
\text { development }\end{array}$} & \multirow{5}{*}{$\begin{array}{c}\text { Economic } \\
\text { development }\end{array}$} & $\begin{array}{l}\text { GDP per capita } \\
\text { (yuan/person) }\end{array}$ & 0.074 & $\begin{array}{c}\text { China Statistical } \\
\text { Yearbook }\end{array}$ \\
\hline & & $\begin{array}{l}\text { Local fiscal revenue (100 } \\
\text { million yuan) }\end{array}$ & 0.060 & $\begin{array}{c}\text { China Statistical } \\
\text { Yearbook }\end{array}$ \\
\hline & & $\begin{array}{l}\text { Proportion of value added of } \\
\text { tertiary industry to regional } \\
\text { GDP (\%) }\end{array}$ & 0.068 & $\begin{array}{l}\text { China Statistical } \\
\text { Yearbook }\end{array}$ \\
\hline & & $\begin{array}{l}\text { Per capita disposable income } \\
\text { of residents (yuan) }\end{array}$ & 0.069 & $\begin{array}{c}\text { China Statistical } \\
\text { Yearbook }\end{array}$ \\
\hline & & $\begin{array}{c}\text { Household consumption } \\
\text { level (yuan) }\end{array}$ & 0.026 & $\begin{array}{c}\text { China Statistical } \\
\text { Yearbook }\end{array}$ \\
\hline & \multirow{5}{*}{ Social Security } & $\begin{array}{l}\text { Urban population density } \\
\text { (people } / \mathrm{km} 2)\end{array}$ & 0.082 & $\begin{array}{c}\text { China Statistical } \\
\text { Yearbook }\end{array}$ \\
\hline & & $\begin{array}{l}\text { Proportion of illiterate } \\
\text { population in population } \\
\text { aged } 15 \text { and over }(\%)\end{array}$ & 0.088 & $\begin{array}{c}\text { China Statistical } \\
\text { Yearbook }\end{array}$ \\
\hline & & $\begin{array}{c}\text { Urban registered } \\
\text { unemployment rate }(\%)\end{array}$ & 0.075 & $\begin{array}{c}\text { China Statistical } \\
\text { Yearbook }\end{array}$ \\
\hline & & $\begin{array}{c}\text { Urban Basic Medical } \\
\text { Insurance Participation Rate } \\
(\%)\end{array}$ & 0.079 & $\begin{array}{c}\text { China Statistical } \\
\text { Yearbook }\end{array}$ \\
\hline & & $\begin{array}{l}\text { Number of health } \\
\text { technicians per } 10,000 \\
\text { people (person) }\end{array}$ & 0.039 & $\begin{array}{c}\text { China Statistical } \\
\text { Yearbook }\end{array}$ \\
\hline & \multirow{5}{*}{ Ecosystem } & Forest cover rate $(\%)$ & 0.124 & $\begin{array}{c}\text { China Statistical } \\
\text { Yearbook }\end{array}$ \\
\hline & & $\begin{array}{l}\text { Sulfur dioxide emissions } \\
\text { (tonnes) }\end{array}$ & 0.057 & $\begin{array}{c}\text { China Statistical } \\
\text { Yearbook }\end{array}$ \\
\hline & & NOx emissions (tonnes) & 0.077 & $\begin{array}{c}\text { China Statistical } \\
\text { Yearbook }\end{array}$ \\
\hline & & $\begin{array}{l}\text { Harmless treatment rate of } \\
\text { domestic garbage }(\%)\end{array}$ & 0.037 & $\begin{array}{c}\text { China Statistical } \\
\text { Yearbook }\end{array}$ \\
\hline & & $\begin{array}{c}\text { Green coverage of built-up } \\
\text { area }(\%)\end{array}$ & 0.046 & $\begin{array}{c}\text { China Statistical } \\
\text { Yearbook }\end{array}$ \\
\hline
\end{tabular}

\section{Empirical Analysis of the Coupling Coordination of Sports Industry and Regional Sustainable Development}

\subsection{Comprehensive Level Analysis of Sports Industry and Regional Sustainable Development}

It can be seen from Table 3 that, from 2013 to 2017, the comprehensive level of the sports industry and regional sustainable development in eastern China showed a steady growth trend, and shows a cyclical change pattern of increasing year by year. The overall average value of the regional sustainable development composite index was 0.463 , and the overall average value of the sports industry composite index was 0.354 , indicating that the overall level of regional sustainable development is better than the overall level of the sports industry, and that the eastern region of China, as a whole, is lagging behind. It can be seen from the growth rate that, from 2013 to 2017, the comprehensive index of the sports industry increased from 0.297 to 0.416 , with a growth rate of $40.07 \%$; the regional sustainable development comprehensive index increased from 0.415 to 0.530 , with a growth rate of $27.71 \%$. It shows that the 
current comprehensive level of the sports industry is developing at a high speed, and the growth rate is significantly higher than regional sustainable development.

Table 3. Comprehensive index of sports industry and regional sustainable development and indexes of various subsystems (2013-2017).

\begin{tabular}{cccccccc}
\hline System (Subsystem) & $\mathbf{2 0 1 3}$ & $\mathbf{2 0 1 4}$ & $\mathbf{2 0 1 5}$ & $\mathbf{2 0 1 6}$ & $\mathbf{2 0 1 7}$ & Population Mean & Growth Rate \\
\hline $\begin{array}{c}\text { Sports Industry } \\
\text { Comprehensive Index }\end{array}$ & 0.297 & 0.331 & 0.346 & 0.380 & 0.416 & 0.354 & $40.07 \%$ \\
$\quad$ Economic benefits & 0.068 & 0.084 & 0.083 & 0.092 & 0.100 & 0.085 & $47.06 \%$ \\
$\quad \begin{array}{c}\text { Employment effect } \\
\text { Support conditions }\end{array}$ & 0.093 & 0.137 & 0.116 & 0.133 & 0.153 & 0.120 & $64.52 \%$ \\
$\quad \begin{array}{c}\text { Regional Sustainable } \\
\quad \text { Development }\end{array}$ & 0.144 & 0.150 & 0.154 & 0.163 & 0.150 & $18.98 \%$ \\
$\begin{array}{c}\text { Comprehensive Index } \\
\text { conic development }\end{array}$ & 0.080 & 0.091 & 0.103 & 0.119 & 0.130 & 0.105 & $27.71 \%$ \\
$\quad \begin{array}{c}\text { Social Security } \\
\text { Ecosystem }\end{array}$ & 0.157 & 0.155 & 0.156 & 0.163 & 0.184 & 0.163 & $62.50 \%$ \\
\hline
\end{tabular}

In the sports industry system, the overall average situation reflects that the development level of industrial support conditions is better than employment absorption and economic benefits. After more than 20 years of rapid development in China's sports industry, contradictions in the industrial structure, supply and demand structure, and consumption structure have become increasingly prominent. For example, the average annual compound growth rate of sports employees is significantly lower than the growth rate of the added value of the sports industry, the growth rate of sports venues is much lower than the development rate of the sports industry, and residents 'sports consumption aspect and consumption levels need to be further improved [49]. Therefore, the contradiction between the "supply-side" and the "demand-side" of the Chinese sports industry is an important factor affecting the further improvement of the comprehensive level of the sports industry. With the successive release of the "46 Document" and other policies that promote the development of the sports industry in 2014, "Accelerate the development of the sports industry" has become a national strategy, and the structural reform of the supply side of the sports industry has received great attention and a positive response from all walks of life. Therefore, from the growth rates in Table 3, from 2013 to 2017, the growth rate of the economic benefits and employment effects of the sports industry was significantly higher than the industry support, and the internal structure of the sports industry is gradually developing from imbalance to overall balance.

In the regional sustainable development system, the overall average shows that the level of ecological environment is superior to the level of social security and economic development. As is known, the basic connotation of maintaining regional sustainable development is the coordinated development of social economy and ecological environment. China announced in November 1998 the implementation of the "National Ecological Environment Construction Plan", which requires that the trend of ecological environment destruction be basically curbed by 2010, and that a virtuous cycle of natural ecosystems is achieved nationwide by 2030. On the basis of curbing the trend of ecological deterioration, and striving to significantly improve the ecological environment of the country, the ecological environment of key governance areas has begun to track a virtuous circle. The eastern region includes the Yangtze River Delta (Shanghai, Jiangsu, Zhejiang), China's most comprehensive economic center, the Bohai Rim region (Beijing, Tianjin, Hebei, Liaoning, and Shandong) with rich natural resources and the high degree of opening Strait Economic Zone (Fujian, Guangdong). With the implementation of the State Council's "Registration of Tianjin City Master Plan (Nation Letter [2006] No. 62)" and the "Yangtze River Delta Regional Planning", the demonstration base in eastern China has accelerated the transformation of economic development mode and the innovation ability has been continuously enhanced, technological support for industrial development has been continuously 
strengthened, and significant results have been achieved in energy conservation and consumption reduction. Therefore, from 2013 to 2017, the growth rate of economic development was significantly ahead of the ecological environment and social security, and the socio-economic level showed a rapid development trend. Based on this, under a good ecological environment, gradually increasing social security and superior socio-economic environment, the comprehensive level of regional sustainable development in eastern China has made greater progress on the existing basis.

The comprehensive level of the sports industry in eastern China from 2013 to 2017 is shown in Figure 1. The overall development level of the sports industry in various provinces and cities shows an upward trend, but there are large differences between regions. Taking the average value of each year as the dividing line, the provinces with a composite index higher than the average are Jiangsu, Guangdong, Shandong, Zhejiang, and Beijing, of which Jiangsu and Guangdong are in a leading position in the eastern region with obvious advantages. The provinces with a composite index below the average are Hebei, Fujian, Shanghai, Liaoning, Tianjin, and Hainan. The comprehensive level of the sports industry in Hainan Province is significantly different from other provinces, and there is a lot of room for improvement. It can be seen that there is an uneven polarization in the development of the sports industry in eastern China.

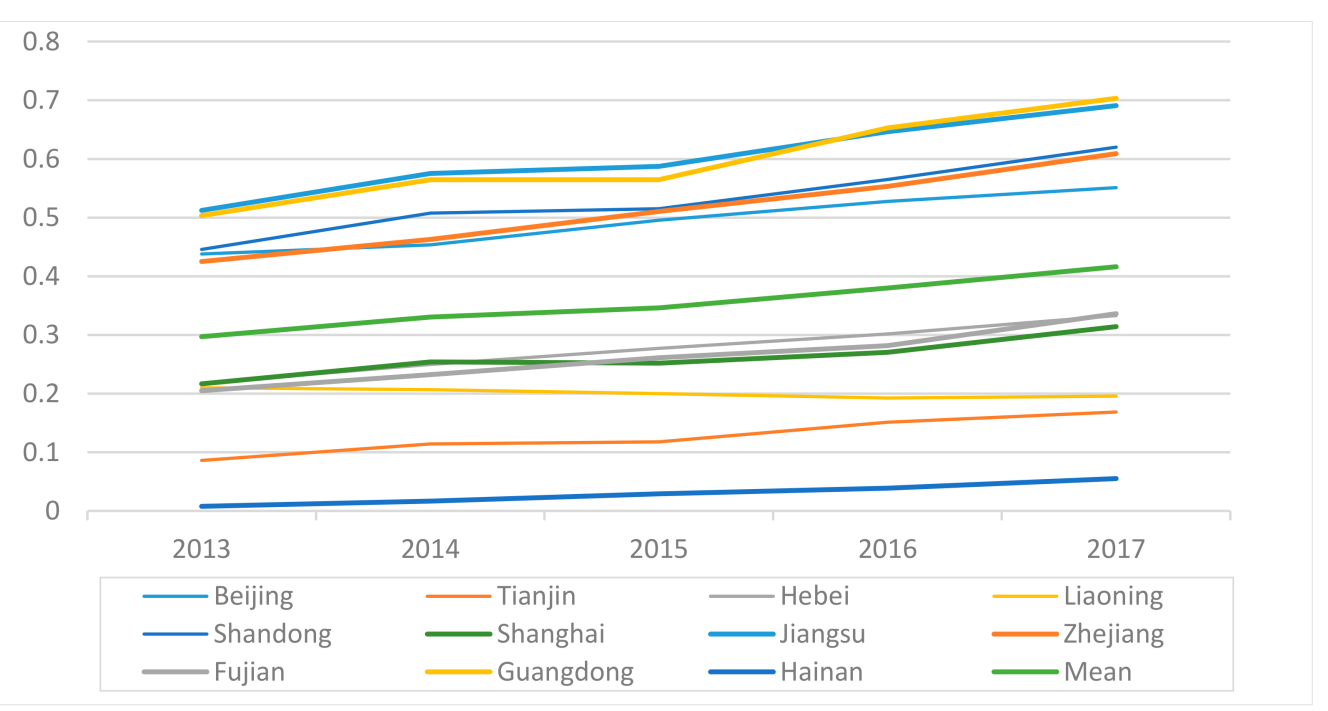

Figure 1. The comprehensive level of the sports industry in eastern China from 2013 to 2017.

The comprehensive level of regional sustainable development in eastern China from 2013 to 2017 is shown in Figure 2. Except for Beijing, which continued to maintain a growth trend after a slight fluctuation in 2015, the remaining provinces and cities in the eastern region showed steady growth each year. Among them, Beijing, Guangdong, Shanghai, and Zhejiang have always been ahead of other provinces in the eastern region with obvious advantages, ranking first in the eastern region. The comprehensive sustainable development levels of Tianjin, Fujian, and Hainan are in the second echelon of the eastern region; the four provinces of Liaoning, Jiangsu, Shandong, and Hebei are in the third echelon of the eastern region with a large gap. It is worth mentioning that, as a province of the Yangtze River Delta, the comprehensive level of economic development of Jiangsu is third in the eastern region, just after Beijing and Shanghai. However, it is affected by the backwardness of social security and ecological environment levels, leading to Jiangsu's comprehensive level of sustainable development being at the end of the eastern region (9th). 


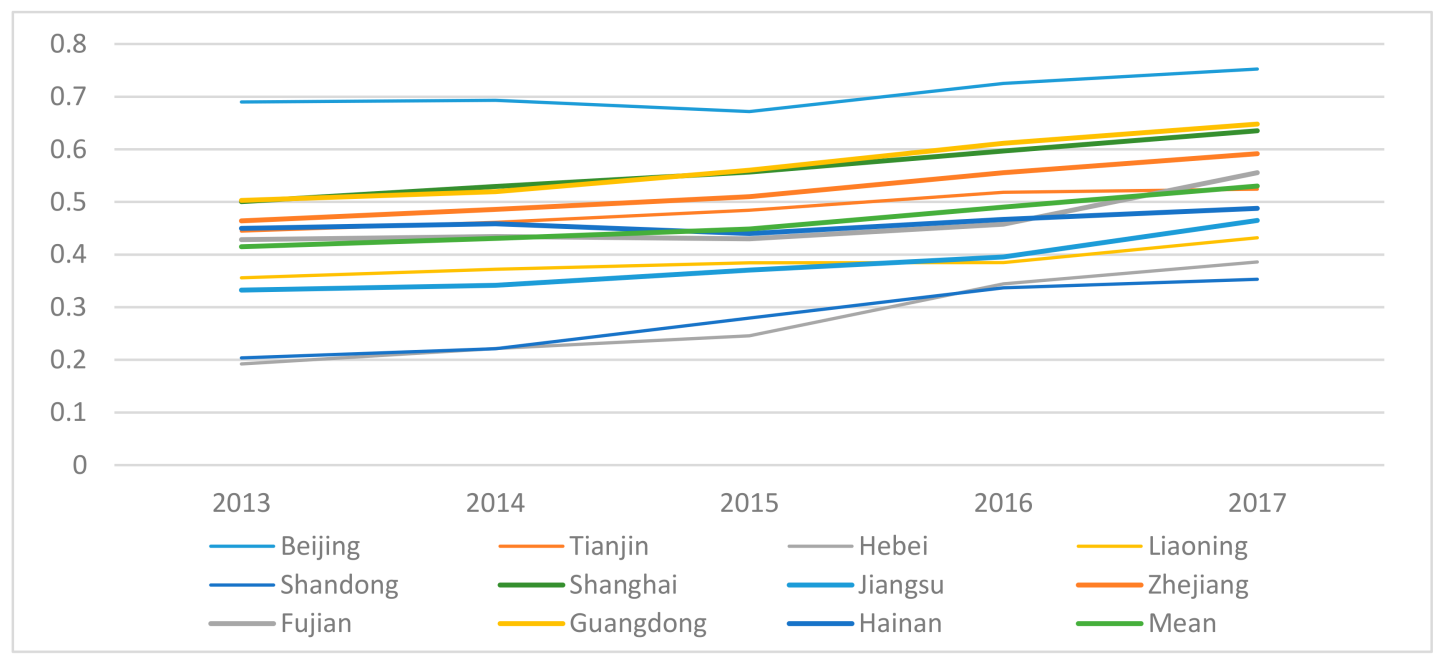

Figure 2. The comprehensive level of regional sustainable development in eastern China from 2013 to 2017.

When examining whether the comprehensive level of the sports industry and regional sustainable development is synchronized, $U$ and $G$, respectively, represent the comprehensive level index of the sports industry and regional sustainable development. When $\mathrm{U}=\mathrm{G}$, it means that the two systems are in synchronous development; when $U>G$, it indicates that the development of the sports industry is superior to regional sustainable development, which is a lag in regional sustainable development; when $U<G$, it indicates that the development of the sports industry lags behind regional sustainable development, which is a lag in the sports industry [47].

As can be seen from Table 4, from 2013 to 2017, the number of lagging sports industries in 11 provinces and cities in eastern China was greater than that of regional sustainable development, which again shows that the comprehensive level of regional sustainable development in eastern China is better than the comprehensive level of the sports industry. From a comparative analysis of 11 provinces and cities, it can be seen that Shandong, Jiangsu, and Guangdong all experienced regional sustainable development lags in the last five years, indicating that the development level of the sports industry in these three provinces is higher than regional sustainable development. Beijing, Tianjin, Liaoning, Shanghai, Fujian, Hainan and the other six provinces and cities all had lagging sports industries; Hebei and Zhejiang show the coexistence of sports industry lagging and regional sustainable development lagging, indicating that the two systems of the two provinces are interacting with each other.

Table 4. Relative development types of sports industry and regional sustainable development.

\begin{tabular}{cccccc}
\hline Year & $\mathbf{2 0 1 3}$ & $\mathbf{2 0 1 4}$ & $\mathbf{2 0 1 5}$ & $\mathbf{2 0 1 6}$ & $\mathbf{2 0 1 7}$ \\
\hline Beijing & Sports lag & Sports lag & Sports lag & Sports lag & Sports lag \\
Tianjin & Sports lag & Sports lag & Sports lag & Sports lag & Sports lag \\
Hebei & Regions lag & Regions lag & Sports lag & Sports lag & Sports lag \\
Liaoning & Sports lag & Sports lag & Sports lag & Sports lag & Sports lag \\
Shandong & Regions lag & Regions lag & Regions lag & Regions lag & Regions lag \\
Shanghai & Sports lag & Sports lag & Sports lag & Sports lag & Sports lag \\
Jiangsu & Regions lag & Regions lag & Regions lag & Regions lag & Regions lag \\
Zhejiang & Sports lag & Sports lag & Regions lag & Sports lag & Regions lag \\
Fujian & Sports lag & Sports lag & Sports lag & Sports lag & Sports lag \\
Guangdong & Regions lag & Regions lag & Regions lag & Regions lag & Regions lag \\
Hainan & Sports lag & Sports lag & Sports lag & Sports lag & Sports lag \\
\hline
\end{tabular}




\subsection{Grade Analysis of the Degree of Coupling Coordination between the Sports Industry and Regional} Sustainable Development

The comprehensive index of the sports industry and regional sustainable development in the 11 provinces and cities in the eastern region were added into the calculation formula of the coupling coordination model, and the degree of coupling coordination between the two major systems of the sports industry and regional sustainable development was calculated (Table 5).

Table 5. The degree of coupling coordination between the sports industry and regional sustainable development.

\begin{tabular}{ccccccc}
\hline Year & $\mathbf{2 0 1 3}$ & $\mathbf{2 0 1 4}$ & $\mathbf{2 0 1 5}$ & $\mathbf{2 0 1 6}$ & $\mathbf{2 0 1 7}$ & Average Value \\
\hline Beijing & 0.74143 & 0.748931 & 0.759601 & 0.786631 & 0.802499 & 0.767818 \\
Guangdong & 0.709379 & 0.735909 & 0.758249 & 0.794865 & 0.821747 & 0.76403 \\
Zhejiang & 0.666515 & 0.688589 & 0.714479 & 0.744647 & 0.774844 & 0.717815 \\
Jiangsu & 0.642486 & 0.665809 & 0.68302 & 0.711185 & 0.752836 & 0.691067 \\
Shanghai & 0.573916 & 0.605597 & 0.611925 & 0.633793 & 0.668399 & 0.618726 \\
Shandong & 0.549011 & 0.578873 & 0.61592 & 0.660485 & 0.684048 & 0.617667 \\
Fujian & 0.544347 & 0.563775 & 0.579077 & 0.599223 & 0.657536 & 0.588792 \\
Liaoning & 0.522964 & 0.526628 & 0.526528 & 0.521877 & 0.539121 & 0.527424 \\
Hebei & 0.452527 & 0.485075 & 0.510948 & 0.567783 & 0.598884 & 0.523043 \\
Tianjin & 0.442518 & 0.479147 & 0.488675 & 0.529142 & 0.545483 & 0.496993 \\
Hainan & 0.244847 & 0.295345 & 0.337445 & 0.366527 & 0.405048 & 0.329842 \\
average value & 0.553631 & 0.579425 & 0.598715 & 0.628742 & 0.659131 & 0.603929 \\
\hline
\end{tabular}

As shown in Table 5, the degree of coupling coordination between the sports industry and regional sustainable development in the eastern region increased from 0.554 in 2013 to 0.659 in 2017. The level of coupling coordination has gradually changed from barely coordinated to primary coordination, and the degree of coupling coordination between the two systems has been significantly improved, indicating that the interaction between the two major systems is constantly strengthened, and the coupling coordination relationship is developing in a benign direction. From the average value of the coupling coordination degree of the two systems over the past five years, we can see that there are six provinces in the level of coupling coordination that are stable, namely Beijing, Guangdong, and Zhejiang, which are at the moderate coordination level, and Jiangsu, Shanghai, and Shandong, which are at the primary coordination level. The level of coupling coordination of these six provinces and cities is in the leading position, mainly because the Yangtze River Delta, formed of Shanghai, Jiangsu, and Zhejiang is China's most important economic center and an important global advanced manufacturing base. Beijing, as China 's national center city, is also the host of the Olympic Games, and Guangdong Province is China 's largest economy and sports province; therefore, the six provinces rely on the unique advantages of the sports industry and region for the two systems to interconnect and promote each other. This has a positive impact on the coupling coordination of the two major systems. There are four provinces with a level of coupling coordination at the initial stage, of which Fujian, Liaoning and Hebei are marginal coordination levels. Tianjin is on the verge of imbalance. Hainan Province is in its infancy, with a mild imbalance.

In order to horizontally compare the coupling coordination between the sports industry and regional sustainable development in 11 provinces and cities in the eastern region, this paper uses ARCGIS 10.2 software to visualize the spatial coordination levels of the two major systems in the 11 provinces and cities in the eastern region in 2013 and 2017. From the perspective of the province, from Figure 3a, it can be seen that, in 2013, 11 provinces in the eastern region had large spatial differences in the degree of coupling coordination of the sports industry and regional sustainable development. There were four provinces in the stable stage. Guangdong and Beijing have the best development levels, with an intermediate level of coordination, followed by Jiangsu and Zhejiang, with a primary level of coordination, indicating that the level of integration and development between the two systems has been relatively stable in 2013 , and tends to be mature. There are six provinces in their infancy: four 
provinces in Fujian, Shandong, Shanghai, and Liaoning are at the level of bare coordination, and Hebei and Tianjin are at the level of about to be imbalanced, indicating that, in 2013, the two major systems in the six provinces have begun to integrate and develop. Due to the special geographic location of the "Island Effect" in Hainan, the level of coupling coordination between the two systems is moderately imbalanced, and there is a large gap with other provinces and cities. As can be seen from Figure $3 b$, in 2017, except for the level of coupling coordination in Liaoning, which remained the same as in 2013, the level of the degree of coupling coordination of the sports industry and regional development in the remaining 10 provinces and cities in the eastern region has significantly improved, but there are still significant spatial differences. Beijing and Guangdong have been upgraded from intermediate coordination to good coordination, indicating that, after five years of development, the integration of the two major systems of the sports industry and regional sustainable development has become relatively mature. From the original moderate imbalance, Hainan has been upgraded two levels to imminent imbalance, which shows that, in recent years, with the support of policies and the cultivation of sports tourism projects such as "Coastal Leisure Sports", the integrated development of the two major systems in Hainan has already begun and is in the initial development stage.
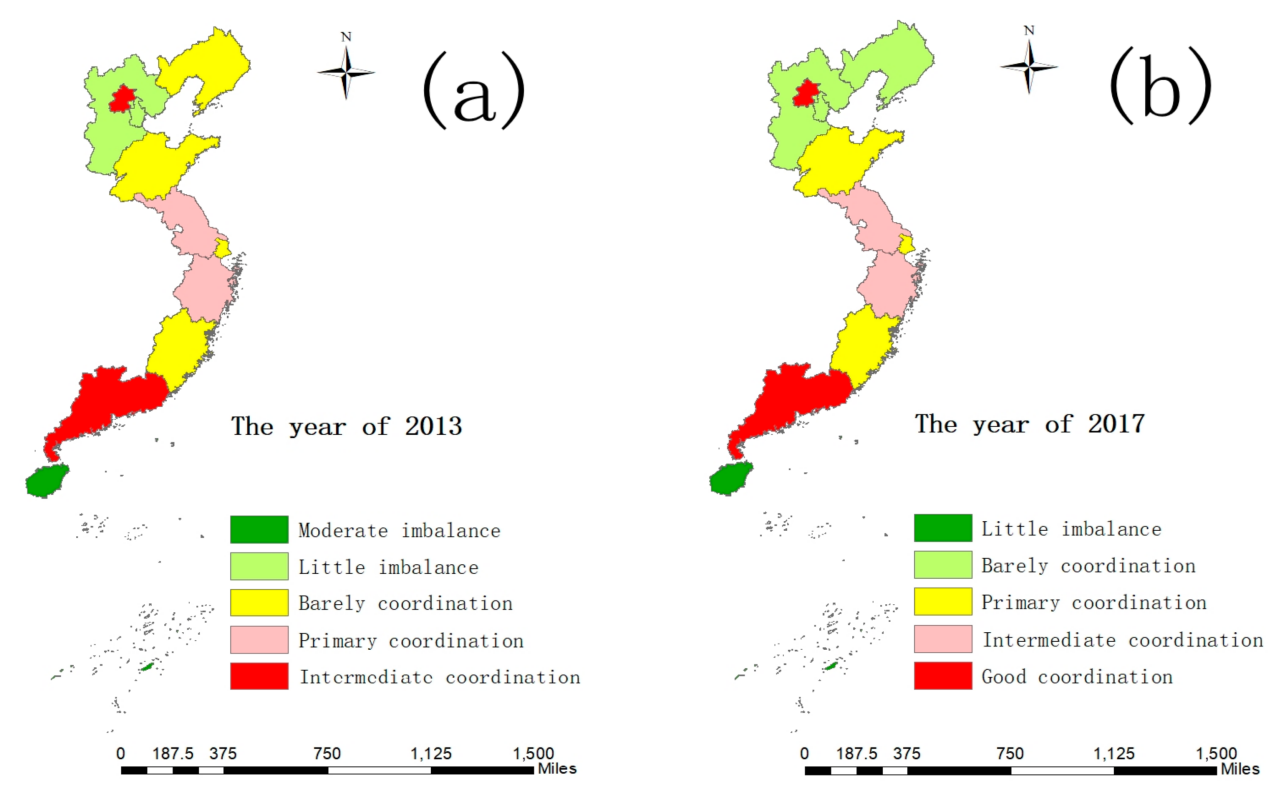

Figure 3. Spatial differences in the levels of coupling coordination between the two major systems of eleven provinces and cities in the eastern region in 2013 and 2017((a) for 2013 and (b) for 2017).

In order to further explore the spatial correlation between the degree of coupling coordination of the sports industry and regional sustainable development in 11 provinces and cities in the eastern region, we used the ARCGIS 10.2 software to calculate the Moran index of the coupling coordination of the two major systems in 2013 and 2017, respectively: when it is larger than 0, it indicates that there is positive spatial correlation; when it is less than 0 , it indicates that there is negative spatial correlation; when the value is close to 0 , it indicates that the degree of spatial correlation is low or randomly distributed [50]. It can be seen from Figure 4 that the Moran indices in 2013 and 2017 were -0.2801 and -0.191 , respectively, and the $\mathrm{Z}$ scores were -0.77 and -0.41 , indicating that the pattern is randomly distributed in space and there is no spatial aggregation phenomenon. Therefore, the spillover effect of the coupling coordination of the two major systems of the 11 provinces and cities in the eastern region is insufficient, and there is a phenomenon of own development, and this phenomenon has persisted for a long time. 


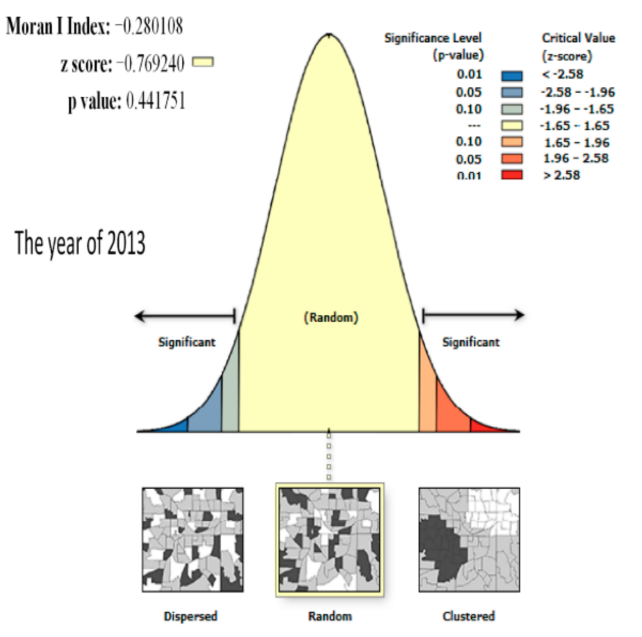

The $z$ score is -0.77 , and the difference between this mode and the random mode is not significant

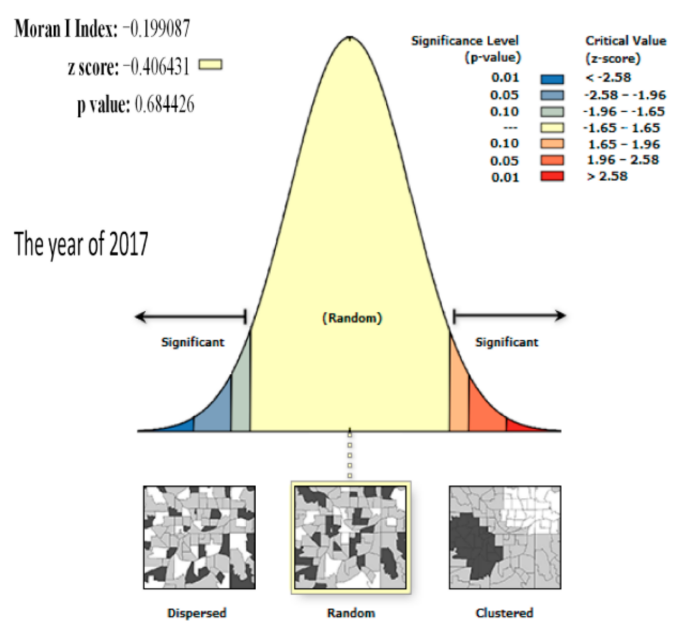

The $\mathrm{z}$ score is -0.41 , and the difference between this mode and the random mode is not significant

Figure 4. Spatial auto-correlation reports of the degree of coupling coordination between the two major systems of 11 provinces and cities in eastern regions in 2013 and 2017.

\section{Driving Factors Analysis for the Coupling Coordination of the Sports Industry and Regional Sustainable Development}

The coupling coordination of the sports industry and regional sustainable development is a systematic project, and the factors affecting its coupling coordination are many and complex. Drawing on relevant research results $[47,51]$, this paper selects the degree of coupling coordination as the explanatory variable, and uses economic development, regional innovation, industrial structure upgrade, government capacity, human capital, and market demand as explanatory variables for quantitative analysis, which are shown in Table 6. The calculation of the industrial structure level coefficient refers to the calculation method of Jing [52]. The original data of all explanatory variables are from the statistical yearbook officially released by the National Bureau of Statistics of China.

Table 6. Coupling coordination dynamic factor index system.

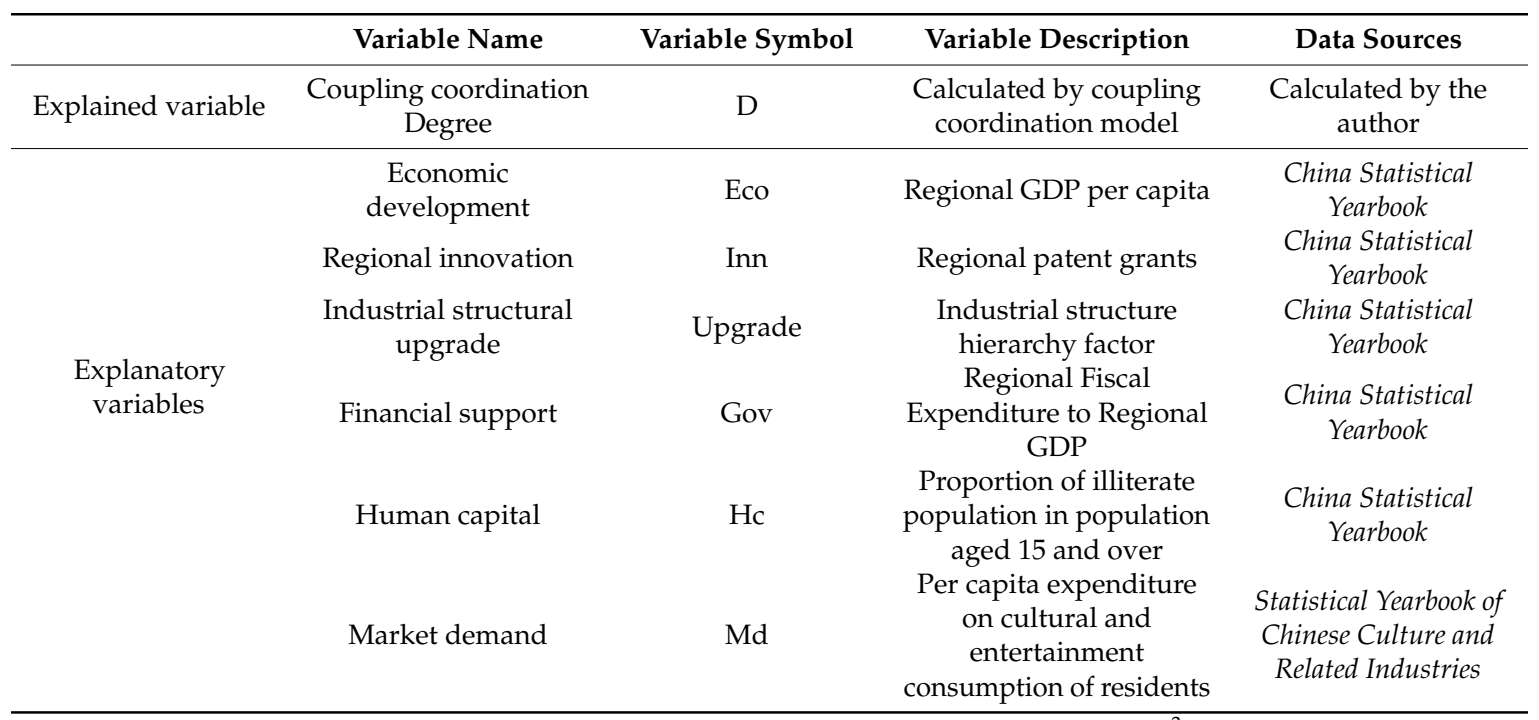

Note: The formula for calculating the industrial structure level coefficient Upgrade $=\sum_{i=1}^{3} q_{i} \times i$, where $q_{i}$ is the proportion of the $i$ industry output value.

\subsection{Stationary Test and Cointegration Unit Root Test}

In the panel data regression analysis, in order to avoid the phenomenon of "false regression", this article refers to the experience of previous scholars and performs unit root and stationarity tests before 
data analysis [53-55]. In the following, the Levin-Lin-Chu (LLC) and Fisher-ADF tests method are mainly adopted to perform unit root tests on variables. From the test results in Table 7, it can be seen that the degree of coupling coordination, innovation power and endogenous power are shown as a stable sequence, and outward power, government power, human resources power and demand power are shown as a first-order stable sequence.

Table 7. The results of the unit root test of the variables.

\begin{tabular}{|c|c|c|c|}
\hline Variable & LLC & Fisher-ADF & Stationary \\
\hline $\mathrm{D}$ & $-6.0576^{* * *}$ & $84.6922 * * *$ & stationary \\
\hline LnECO & 0.3651 & 4.4165 & \multirow{2}{*}{ first-order stationary } \\
\hline D.LnECO & $-8.1592^{* * *}$ & $39.9006^{* *}$ & \\
\hline LnINN & $-9.4366^{* * *}$ & $128.8757^{* * *}$ & stationary \\
\hline LnUpgrade & $-8.6401^{* * *}$ & $113.1060^{* * *}$ & stationary \\
\hline GOV & -3.1681 & 18.9340 & \multirow{2}{*}{ first-order stationary } \\
\hline D.GOV & $-9.1726^{* * *}$ & $34.3567 * *$ & \\
\hline $\mathrm{HC}$ & $-6.9550 * * *$ & 33.0095 & \multirow{2}{*}{ first-order stationary } \\
\hline D.HC & $-16.6517^{* * *}$ & $112.3428^{* * *}$ & \\
\hline LnMD & -4.2 & 20.1490 & \multirow{2}{*}{ first-order stationary } \\
\hline D.LnMD & $-6.4980^{* * *}$ & $43.6024 * * *$ & \\
\hline
\end{tabular}

Co-integration and regression analysis cannot be performed due to the inconsistency of the variables, but the first-order stationary variable after difference processing is a stationary sequence. Therefore, this article draws on previous studies, and this paper selects the variables after the first-order stationary variable difference for analysis [56], using mixed regression analysis on the original stationary variable and the variable after the difference and taking a unit root test on the residuals. In this paper, the stationary test of the residual sequence is performed. The specific results are shown in Table 8 . The result rejects the null hypothesis, that is, the residual appears as a stationary sequence, therefore the co-integration relationship exists and regression analysis can be performed.

Table 8. The stationary test of the residual sequence.

\begin{tabular}{cccc}
\hline Variable & LLC & Fisher-ADF & Stationary \\
\hline Residual & $-21.1963^{* * *}$ & $110.7750^{* * *}$ & stationary \\
\hline \multicolumn{4}{c}{ Note: ${ }^{* * *}$ denote a significance of $1 \%}$.
\end{tabular}

\subsection{Regression Analysis}

As can be seen from Table 9, the results of the Hausman test are not significant, so a random effect model is selected for analysis. At the same time, based on the panel data of eleven provinces and cities in the eastern region from 2013 to 2017, a measurement model for the dynamic factors of coupling and coordinated development is established, as follows.

$$
D_{i t}=\beta_{1}+\beta_{2} \text { D.Lneco }_{i t}+\beta_{3} \text { Lninn }_{i t}+\beta_{4} \text { Lnupgrade }_{i t}+\beta_{5} D \cdot G O V_{i t}+\beta_{6} D \cdot H C_{i t}+\beta_{7} D \cdot \text { Lnmd }_{i t}+\mu_{i}+\varepsilon_{i t}
$$


Table 9. The regression results of the coupled and coordinated development dynamics factors.

\begin{tabular}{ccc}
\hline & Fixed Effect Model & Random Effects Model \\
\hline \multirow{2}{*}{ D.LnECO } & 0.0594 & 0.0580 \\
& $(0.91)$ & $(1.10)$ \\
\hline \multirow{2}{*}{ LnINN } & 0.0549 & $0.0800^{* * *}$ \\
& $(1.48)$ & $(9.85)$ \\
\hline \multirow{2}{*}{ LnUpgrade } & $1.5821^{*}$ & $0.5733^{* *}$ \\
& $(1.97)$ & $(2.37)$ \\
\hline \multirow{2}{*}{ D.GOV } & $-0.4180^{*}$ & $-0.3452^{* * *}$ \\
& $(-2.14)$ & $(-3.58)$ \\
\hline \multirow{2}{*}{ D.HC } & $-0.0148^{*}$ & $-0.0207^{* * *}$ \\
& $(-2.03)$ & $(-3.85)$ \\
\hline \multirow{2}{*}{ D.LnMD } & 0.0112 & -0.0526 \\
& $(0.19)$ & $(-1.03)$ \\
\hline \multirow{2}{*}{ cons } & $-8.6955^{*}$ & $-3.4115^{* * *}$ \\
& $(-2.12)$ & $(-2.71)$ \\
\hline $\mathrm{N}$ & 44 & 44 \\
$\mathrm{~F}$ & 37.1379 & 516.06 \\
$\mathrm{R}{ }^{2}$ & 0.8126 & 0.7751 \\
$\mathrm{p}$ & 0.0000 & 0.0000 \\
\hline
\end{tabular}

Hausman test: $\lambda^{2}=5.88, P=0.4372$

Note: ${ }^{* *}, * *$ and $*$ denote a significance of $1 \%, 5 \%$ and $10 \%$, respectively, $\mathrm{T}$ values are shown in parentheses.

In the formula, $D$ is the explanatory variable, which indicates the degree of coupling coordination, D.lneco, the differential variable for economic development and the change in economic development; Lninn is the regional innovation; Lnupgrade is the industrial structure upgrade; D.gov is the differential variable for financial support representing the change in financial support; D.HC is the differential variable of human capital, which represents the change in human capital; D.lnmd is the differential variable of market demand, which represents the change in market demand; $\mu$ is the individual fixed effect; and $\varepsilon$ is the individual random effect.

In the regression results of random effects, the two variables of regional innovation and industrial structure upgrade have a significant positive impact on the degree of coupling coordination, indicating that strengthening the regional innovation ability and improving the industrial structure upgrade can significantly positively affect the degree of coupling coordination, and have a positive impact on the integration and promotion of industry and regional sustainable development. The change in financial support has a significant negative impact on the degree of coupling coordination, indicating that with the increase in financial support input, the coupling coordination of the sports industry and regional sustainable development will be suppressed to a certain extent. In conjunction with the literature, some scholars have pointed out that the local financial investment in sports industry guidance funds, on the one hand, promotes the development of the sports industry layout, but it has caused risks such as market order disruption, loss of pulling efficiency, lack of project performance, and loss of guidance funds due to problems in the allocation review management mechanism, project structure investment, funding support methods, and later management [57]. At the same time, sports public financial expenditure is more about investing in the consumption base of the sports industry, and, according to the current development characteristics of the Chinese market economy and the structure of the sports industry, the development of the sports industry ultimately depends on the market, not the government [58]. Therefore, increasing financial support is not the only way to significantly improve the integration of the sports industry and regional development. The change in human capital has a significant negative impact on the degree of coupling coordination. This paper selects the proportion of illiterate people over the age of 15 as the evaluation index of human capital. This index 
is a negative index, which indicates that enhancing the training of talents and improving the level of residents' culture can promote coupling coordination. Economic development and market demand have no significant impact on the degree of coupling coordination. Due to the low original level of per capita sports consumption expenditure in China and the short development time, the service demand generated by sports consumption cannot be generated in a short time and requires a cumulative effect over time. Therefore, the level of economic development and market consumer demand have a smaller impact on the coupling coordination of the sports industry and regional sustainable development.

\section{Research Conclusions and Countermeasures}

\subsection{Research Conclusions}

Under the context of a "sports power", the current stage is an important period for China's sports industry to transition from high-speed development to high-quality development. The development of the sports industry has become an important force for economic transformation and upgrade. Its coordination and integration with regional sustainable development are an integral part of the modern economy. Therefore, exploring the current status of the coupling and coordination of the two is of great significance for promoting the transformation of the sports industry and the synchronous development of the sports industry and regional sustainable development. It not only promotes the sustainable development of the sports industry and regional economy, but also promotes the long-term progress of the whole society. This paper first discusses the comprehensive level of the sports industry and regional sustainable development in eastern China and the characteristics of the degree of coupling and coordination by constructing a coupling index system for the sports industry and regional sustainable development, using an entropy method and a coupling coordination model and by constructing a dynamic factor index system of the coupling coordination degree, and using a panel data regression model to analyze the dynamic factors affecting the coupling coordination degree.

The research indicates:

(1) From 2013 to 2017, the comprehensive level of the sports industry and regional sustainable development in eastern China showed a steady growth trend. The comprehensive level of regional sustainable development is better than the comprehensive level of the sports industry; the eastern region generally is a sports industry lagging type. It can be seen from the growth rate that, for five years, the comprehensive level of the sports industry is growing faster than regional sustainable development. With the support of relevant policies for the development of the sports industry, the level of development of the economic benefits and employment effects of the sports industry has been rapidly improved, and the internal structure of the sports industry is gradually undergoing an overall balanced development. In the regional sustainable development system, the growth rate of the economic development level is faster than the ecological environment and social security;

(2) From the perspective of the province, the comprehensive level of the sports industry in various provinces and regional sustainable development basically showed steady growth from 2013 to 2017 . However, there is an uneven polarization in the comprehensive level of the sports industry. Jiangsu and Guangdong are in the leading position, and Tianjin and Hainan are at the end. There are also large gaps in the comprehensive level of regional sustainable development. Among them, Beijing and Guangdong have the best development, whereas Shandong and Hebei have large gaps with other provinces and are in the bottom position. From 2013 to 2017, Shandong, Jiangsu, and Guangdong are lagging regions, Hebei, Zhejiang is where sports industry lagging and regional sustainable development lagging coexist, and the remaining provinces and cities are sports industries lagging;

(3) In terms of the relative development types of the sports industry and regional sustainable development, the provinces with lagging sports industries are significantly more numerous than those with regional lagging sustainable development in eastern China. In terms of different provinces, Shandong, Jiangsu, and Guangdong were provinces with lagging regional development between 2013 
and 2017. Hebei and Zhejiang are both lagging sports industry and regional sustainable development types. The remaining provinces and cities are lagging sports industries type;

(4) Compared to 2013, the overall level of coupling and coordination between the sports industry and regional sustainable development in the eastern region was upgraded to primary coordination in 2017. Among them, Beijing and Guangdong have the best development and are at a good level of coordination. Hainan has shown a strong development trend with the support of national policies, rising from moderate imbalance to imminent imbalance. From the perspective of spatial correlation effect, there is no spatial clustering phenomenon in the coupling and coordination of the sports industry and regional development among the provinces and cities in the eastern region. The spatial spillover effect is insufficient and the promotion effect between neighboring provinces is lacking;

(5) From the perspective of driving factors, regional innovation, industrial structure upgrade, and emphasis on talent training have a significant positive effect on the degree of coupling and coordination. Therefore, in future development, it is necessary to strengthen regional innovation, attach importance to the upgrading of industrial structure, improve the cultural level of residents, and focus on the cultivation of high-end professional and technical personnel. Due to the failure to improve the management system of the investment and use of China's sports industry guidance funds, the government 's financial investment has not had a positive effect on the level of coupling and coordination, but inhibited the natural development of the sports industry to a certain extent, leading to a negative impact on coupling coordination.

\subsection{Suggestions and Advice}

(1) Strengthen cross-regional cooperation and build a cross-regional "sports+" industrial group. The development of the comprehensive level of the sports industry in the eastern region is polarized. Therefore, we should establish the inter-regional coordinated development mechanisms and a cross-regional "sports+" industry group, and strengthen the cooperation and exchanges between related enterprises and groups, and jointly formulate development strategies using contracts, commissions and joint ventures to promote the deep integration of sports and related industries, thereby promoting the balanced development of the sports industry. When vigorously developing the "Sports+" industry group, it is necessary to promote the joint development of related companies from a strategic perspective, promote cooperation and the division of labor between enterprises, and form a "Sports+" industry group with local characteristics to prevent related companies from self-closure and excessive competition. Establishing a strategic cooperative relationship between "sports+" industry groups across regions can promote the mutual complementarity of advantages, break the limitations of resources and technologies, and combine the industrial and economic characteristics of other regions to achieve complementary resources, cooperative development, and to become bigger and stronger, and finally achieve benefit-sharing. For example, Beijing is the region with the best comprehensive level of sports industry in the eastern region, but its neighboring provinces and cities, like Liaoning and Tianjin, are ranked at the end of the eastern region. Therefore, it should strengthen exchanges with neighboring provinces in areas such as technology and talent. Liaoning and Tianjin can learn from the development experience of Beijing's "Olympic Heritage" industry and rely on existing resources to focus on the development of the "National Games Heritage" project. Liaoning is the only province in the Northeast that is both coastal and borderline. It can make full use of its unique geographical and climatic advantages to forming a sports tourism industry with Beijing to attract tourists to experience coastal sports tourism and ice sports tourism, and realize industrial cooperation and common development between neighboring provinces;

(2) Give play to the spillover effect of "sports+" and create a coupling platform for the sports industry and regional sustainable development. The spatial difference between the sports industry and regional sustainable development in the eastern region cannot be ignored. The comprehensive level of the sports industry and the regional sustainable development are the bottlenecks that restrict the coordinated development of the eastern region. The sports industry is a "power industry" and 
has a strong correlation. It can play the role of an "economic coordinator" in the national economy industry. Therefore, the eastern region should give full play to its " $1+1>2$ " spillover effect on "sports+" or "+sports", create a coupling innovation platform for the sports industry and regional sustainable development, and target provinces and cities with lagging sports industry development, and strengthen the radiation-driven role of regional sustainable development and the promotion of regional integration [59], strengthen the integration and development between the sports industry and other industries, and improve the internal and external links between the sports industry and regional sustainable development in all aspects. Aiming at the provinces and cities with lagging regional sustainable development, in the development of the sports industry, we should focus on the shift from quantitative scale to quality-oriented [47], to drive the development of economy, culture, science and technology, ecology, and social security by creating a "sports+" industry and realize the unification of the sports industry and the social benefits of regional sustainable development. Affected by the development of the sports industry in each province and city, the same phenomenon exists in the degree of coupling coordination between the sports industry and regional sustainable development. The spillover effects of neighboring provinces are not obvious. Only a reasonable and scientific combination and connection of the sports industry and regional sustainable development, forming a mature interaction mechanism between the two, and strengthening exchanges and cooperation between provinces, is an effective way to solve the problem of unbalanced development of coupling coordination in the eastern region;

(3) Release the superposition effect of multiple dynamics, and promote the evolution of coupling coordination to a higher level. In order to realize the coordinated evolution of the sports industry and regional sustainable development in the eastern region, it is necessary to fully release the superimposed effects of multiple forces, such as economic development, regional innovation, industrial structure upgrade, government capacity, human capital, and market demand, and strengthen the power of this "booster" to promote the accelerated development, leapfrog development and coordinated development of the eastern region. First, continue to strengthen scientific and technological innovation capabilities, build industrial innovation mechanisms, create industrial technological innovation platforms, promote industrial transformation and upgrading, strive to create a good environment for scientific and technological innovation, rely on technological support to lead the industry to new and modernized transformation, and promote the rapid and healthy development of social economy and living standards. Second, continue to focus on optimizing the upgrading of the industrial structure, and promote the "old tree sprouts the new power" idea of traditional enterprises, so that traditional enterprises are not only the main force of economic development, but also the basis for the cultivation and development of emerging industries, as well as liminating industry monopolies, improving the integration environment of related industries in regional development, strengthening industrial interconnection, adhering to the "market-led, government-regulated" principle, and improving residents' sports consumption aspect and consumption level. Third, actively play a guiding role in the government, establish and improve the policy system for sports industry and regional sustainable development, strengthen policy implementation, cultivate professional talents, improve the level of public services and infrastructure equality, improve the allocation and use system of local sports industry guidance funds and give targeted policy tilt and funding support to different regions according to local conditions.

\section{Research Limitations and Future Prospects}

This article measures the coupling and coordination degree between the sports industry and regional sustainable development with a multi-index evaluation system, but there are also limitations in the construction of the index system. The national statistical indicators for the sports industry are currently simple, which means that the system index system cannot fully reflect the comprehensive level of the sports industry. Therefore, with the continuous optimization and improvement of the statistical system of the Chinese sports industry, a scientific, systematic, and useable index system should be constructed in the future to maximize the credibility of the research results. Besides, the 
above research is based on the provincial-level regional units in eastern China. If more fine-grained data on cities, counties, and regions are used to conduct research on the coupling and coordination of the sports industry and regional sustainable development, it will further reveal the regional differences and driving mechanisms of the coupling and coordination between the two and have greater application value for local governments at all levels to promote the organic integration of the sports industry and regional sustainable development. In addition, due to limited data and sources, this article only analyzes panel data from 2013 to 2017. In the future, more data can be collected, and deeper research in a broader time dimension can be conducted to discover the periodic changes.

Author Contributions: Conceptualization, J.X. and S.Y.; Methodology, J.X.; Software, J.X.; Validation, J.X.; Formal Analysis, J.X. and S.Y.; Investigation, J.X. and S.Y.; Resources, J.X. and S.Y.; Data Curation, J.X. and R.Y.; Writing-Original Draft Preparation, J.X. and S.Y.; Writing-Review and Editing, J.X. and R.Y. All authors have read and agreed to the published version of the manuscript.

Funding: This research was funded by the National Social Science Foundation of China (Grant No. 19ATY006).

Acknowledgments: The authors are thankful to the National Social Science Foundation of China for the full support of this research study.

Conflicts of Interest: The authors declare no conflict of interest.

\section{References}

1. Zhang, J.Q.; Zhang, L.; Wang, C.; Fan, F. Study on regional sustainable development efficiency measurement and influencing factors: Based on DPSIR-DEA Model. China Popul. Resour. Environ. 2017, 11, 1-9.

2. World Environment and Development Commission. Our Common Future; Jilin People's Publishing House: Jilin, China, 1997.

3. Wilbanks, T.J. Sustainable development in geographic perspective. Ann. Assoc. Am. Geogr. 1994, 4, 541-556. [CrossRef]

4. Research Group of Sustainable Development of the Chinese Academy of Sciences. 2002 China Sustainable Development Strategy Report; Science Press: Beijing, China, 2002; p. 2.

5. Lu, D.D.; Fan, J. The Rise and Effects of Regional Sustainable Development Studies in China. Bull. Chin. Acad. Sci. 2012, 3, 290-300.

6. United Nations. Update on the 2030 Agenda for Sustainable Development. Available online: https: //sustainabledevelopment.un.org/post (accessed on 27 September 2015).

7. Xu, J.F.; Yang, R.Y. Sports industry agglomeration and green economic growth-Empirical research based on panel data of 30 provinces and cities in China. Sustainability 2019, 19, 5399. [CrossRef]

8. Wang, X.G.; An, X.X. Optimization of Sports Power Concept under the 2030 Sustainable Development Agenda. J. Beijing Sport Univ. 2018, 3, 1-7.

9. Yi, J.D. About the Development Logic of Sports Industry. J. Sports Res. 2019, 4, 1-12.

10. Zhao, C.S.; Ren, J.L. Research on Coordination and Forecast of China's Tourism Industry and Regional Development from the Perspective of Global Tourism. Inq. Econ. Issues 2018, 3, 66-74.

11. Haughton, G. Sustainable Cites; Jessica Kingsley Publishers: London, UK, 1996; pp. 110-130.

12. Zenk, S.N.; Schulz, A.J.; Israel, B.A.; Mentz, G.; Miranda, P.Y.; Opperman, A.; Odoms-Young, A.M. Food shopping behaviors and exposure to discrimination. Public Health Nutr. 2014, 5, 1167-1176. [CrossRef]

13. Mc, K.; Brian, S. Access to supermarkets among poorer neighborhoods: a comparison of time and distance measures. Urban Geogr. 2014, 1, 133-151.

14. Wardrop, D.H.; Glasmeier, A.K.; Peterson-Smith, J.; Eckles, D.; Ingram, H.; Brooks, R.P. Wetland ecosystem services and coupled socioeconomic benefits through conservation practices in the Appalachian Region. Ecol. Appl. 2011, 3, 93-115. [CrossRef]

15. Khodakarami, M.; Shabani, A.; Saen, R.F. A new look at measuring sustainability of industrial parks: A two-stage data envelopment analysis approach. Clean Technol. Environ. Policy 2014, 8, 1577-1596. [CrossRef]

16. Eustachio, J.H.P.P.; Caldana, A.C.F.; Libomi, L.B.; Martinelli, D.P. Systemic indicator of sustainable development: Proposal and application of a framework. J. Clean. Prod. 2019, 241, 118346. [CrossRef]

17. Li, Y.; Chen, Y.; Liang, L.; Xie, J. DEA models for extended two-stage network structures. Omega 2012, 5, 611-618. [CrossRef] 
18. Zhao, C.S.; Ren, J.L.; Chen, Y.B.; Liu, K. Coupling Coordination and Spatio-temporal Differentiation of Scientific and Technological Innovation and Sustainable Development in China. Sci. Geogr. Sin. 2018, 2, 214-222.

19. Fu, L.P.; Jiang, X.D.; He, L.P. How Natural Resource-Based Industry Affect Sustainable Development? An Evolutionary Study of China. Sustainability 2020, 1, 291. [CrossRef]

20. Smetana, S.; Tamas, Y.C.; Mathys, A.; Heinz, V. Sustainability Assessment of Agribusiness Clusters: A Case Study Based on Regional Sustainability Assessment Methodology. Ger. J. Agric. Econ. 2017, 3, 159-171.

21. Yu, B.B.; Yang, H.X.; Jing, G. Can industrial agglomeration improve regional economic efficiency?-Spatial econometric analysis based on Chinese urban data. J. Zhongnan Univ. Econ. Law 2015, 3, 121-130.

22. Tian, K.M. Analysis of Development and Feasibility of Chinese Sports Industry. J. Beijing Univ. Phys. Educ. 2000, 3, 308-311.

23. Sun, H.C. The status and role of sports in the economic and social development of the new century. J. Wuhan Inst. Phys. Educ. 2000, 5, 1-4.

24. Lu, Y.Z.; Guo, Y.P.; Fei, Q.; Kong, W.Q. Basic theoretic problem of sports industry. J. Phys. Educ. 2001, 1, $41-44$.

25. Xu, W.H.; Zhao, K.; Wang, S.S.; Li, W. Investigation Research of Sports Demonstration Market on Regional Economies and Social Development. China Sport Sci. Technol. 2014, 1, $23-25$.

26. Lu, P.S. The Influence of Northwest China's Traditional Sports Culture on Region Economy. China Sport Sci. Technol. 2002, 11, 6-9.

27. Tan, H.; Zhang, X.L. Sporting Goods Manufacturing Industry and Regional Economic Growth-Empirical Research on Panel Data Collected of 10 Provinces in Eastern. J. Southwest China Norm. Univ. 2017, 9, 67-75.

28. Watson, P.; Davies, S.; Thilmany, D. Determining Economic Contributions in a Recreational Industry An Application to Colorado's Golf Industry. J. Sport Econ. 2008, 6, 571-591. [CrossRef]

29. Baumann, R.W.; Matheson, V.A.; Muroi, C. Bowling in Hawaii Examining the Effectiveness of Sport-Based Tourism Strategies. J. Sport Econ. 2009, 2, 107-123. [CrossRef]

30. Schulenkorf, N.; Giannoulakis, C.; Blom, L. Sustaining Commercial Viability and Community Benefits: Management and Leverage of A Sport-for-Development Event. Eur. Sport Manag. Q. 2019, 1, 502-519. [CrossRef]

31. Li, G.Q.; Zhang, B.Y.; Zhao, M. Integrated and Coordinated Development of Regional Economy, Sports Industry and Mass Sports in China. J. Tianjin Univ. Sport 2015, 1, 87-92.

32. Yao, S.B.; Liu, Y. An Empirical Analysis of the Impact of Sports Industry Agglomeration on Regional Economic Growth-Based on Static and Dynamic Panel Data Model. China Sport Sci. 2017, 11, 21-29.

33. Zhao, C.S.; Ren, J.L. Correlation Analysis between Sci-Tech Innovation and Sustainable Development in China: Empirical Study on Entropy and Grey Relational Model. Ecol. Econ. 2017, 11, 58-61.

34. Cai, Y.S.; Lv, J.W. Evaluation of Regional Development Quality in Beijing-Tianjin-Hebei Region Based on Entropy Method. Ind. Technol. Econ. 2018, 11, 67-74.

35. Sherry, E.; Schulenkorf, N.; Seal, E.; Nicholson, M.; Hoye, R. Sport-for-Development in the South Pacific Region: Macro-, Meso-, and Micro-Perspectives. Sociol. Sport J. 2017, 4, 303-316. [CrossRef]

36. Schulenkorf, N. Sustainable Community Development through Sport and Events: A Conceptual Framework for Sport-for-Development Projects. Sport Manag. Rev. 2012, 1, 1-12. [CrossRef]

37. Schulenkorf, N. Sport Events and Ethnic Reconciliation: Attempting to Create Social Change between Sinhalese, Tamil and Muslim Sportspeople in War-torn Sri Lanka. Int. Rev. Sociol. Sport 2010, 3, $273-294$. [CrossRef]

38. Lindsey, L.; Darby, P. Sport and the Sustainable Development Goals: Where is the policy coherence? Int. Rev. Sociol. Sport 2019, 7, 793-812. [CrossRef]

39. Tong, Y.J.; Tao, W.Y.; Cong, H.P. The Arrangement of Sports Industry Structure and Policy Research in China's Eastern Provinces. China Sport Sci. 2012, 2, 39-49.

40. Sun, B.Y.; Yang, X.H.; Zhang, Y.P.; Chen, X.J. Evaluation of water use efficiency of 31 provinces and municipalities in china using multi-level entropy weight method synthesized indexes and data envelopment analysis. Sustainability 2019, 17, 4556. [CrossRef]

41. Wang, F.X.; Mao, A.H.; Li, H.L. Quality Measurement and Regional Difference of Urbanization in Shandong Province Based on the Entropy Method. Sci. Sin. 2013, 11, 1323-1329. 
42. Xu, X.; Chen, L. Influencing factors of disability among the elderly in China, 2003-2016: application of Bayesian quantile regression. J. Med. Econ. 2019, 6, 605-611. [CrossRef]

43. Shi, T.; Yang, S.Y.; Zhang, W.; Zhou, Q. Coupling coordination degree measurement and spatiotemporal heterogeneity between economic development and ecological environment-Empirical evidence form tropical and subtropical regions of China. J. Clean. Prod. 2020, 244, 118739. [CrossRef]

44. Liu, Y.B.; Li, R.D.; Song, X.F. Analysis of Coupling Degrees of Urbanization and Ecological Environment in China. J. Nat. Resour. 2005, 1, 106-111.

45. Thomas, B.F. Policy, plan and programmed environmental assessment in England, Netherlands, and Germany: practice and prospects. Environ. Plan. B: Plan. Des. 2002, 29, 159-172.

46. Yan, H.L. Research on Coupling Time Series Evolution and Influencing Factors of Sports Events and Host City Development. China Sport Sci. Technol. 2019, 55, 1-8.

47. Ye, S.Z. Research on the Coordination Degree Evaluation of Fusion Development of Sports Industry and Elderly Care Industry-Taking 11 Provinces and Cities in East China as An Example. J. Chengdu Sport Univ. 2019, 2, 62-69.

48. Shi, P.F.; Li, X.M.; Xiong, Y.B. Coupling Measurement and Prospect Forecast of Regional "BeautifulChina" Construction and Tourism Industry Development-A Case Study of 11 Provinces along the Yangtze River Economic Belt. China Soft Sci. 2018, 2, 86-102.

49. Fu, Q.; Wang, P.P.; Chen, W.C. Challenge, Opportunity and Route: The Supply-Side Structural Reform of Sports Industry in China. J. Tianjin Univ. Sport 2019, 1, 44-51.

50. Yang, R.Y.; Chen, W.D. Spatial Correlation, Influencing Factors and Environmental Supervision on Mechanism Construction of Atmospheric Pollution: An Empirical Study on $\mathrm{SO}_{2}$ Emissions in China. Sustainability 2019, 11, 1742. [CrossRef]

51. Zhao, C.S.; Ren, J.L.; Chen, Y.B.; Liu, K. Spatial-temporal coupling and driving forces of China's provincial tourism industry and regional development under the background of comprehensive tourism. Chin. J. Popul. Resour. Environ. 2018, 3, 149-159.

52. Jing, X.Q. Advanced Industrial Structure and Economic Growth: An Empirical Analysis of the Yangtze River Delta Region. J. Nantong Univ. 2005, 3, 45-49.

53. Kao, C. Spurious regression and Residual-Based Tests for Cointegration in Panel Data. J. Econom. 1999, 1, 1-44. [CrossRef]

54. Pedroni, P. Critical Values for Cointegration Tests in Heterogeneous Panels with Multiple Regressors. Oxf. Bull. Econ. Stat. 1999, 61, 653-670. [CrossRef]

55. Pesaran, M.H.; Smith, R. Estimating long-run relationships from dynamic heterogeneous panels. J. Econ. 1995, 68, 79-113. [CrossRef]

56. Deng, Z.B.; Zong, S.W.; Su, C.W.; Chen, Z. Research on the Coordinated Development and Dynamic Factors of Ecological Civilization Construction and New Urbanization in the Yangtze River Economic Belt. Econ. Geogr. 2019, 10, 78-86.

57. Xing, Z.M.; Zhou, L.J. Policy Practices, Distribution Risks and Efficiency Improvement of the Guiding Funds in China's Local Sports Industry Based on the Survey and Analysis in 8 Provinces. China Sport Sci. 2015, 4, 12-21.

58. Feng, G.Y.; Jia, S.H. Research on the Commitment, Practice and Effect of China's Fiscal Policy Support for Sport Industry Development. China Sport Sci. 2018, 9, 37-46.

59. Wu, Z.J. The city cluster in the middle reaches of the Yangtze river and the coordinated path of cooperation. Econ. Geogr. 2015, 3, 60-65.

(C) 2020 by the authors. Licensee MDPI, Basel, Switzerland. This article is an open access article distributed under the terms and conditions of the Creative Commons Attribution (CC BY) license (http://creativecommons.org/licenses/by/4.0/). 